\title{
Tennyson and the Embodied Mind
}

\author{
Gregory Tate
}

Some time after the publication of his book The Principles of Psychology in 1855, Herbert Spencer wrote to Alfred Tennyson:

SIR, coming to the verse

I happened recently to be re-reading your Poem "The Two Voices," and

Or if thro' lower lives I came-

Tho' all experience past became

Consolidate in mind and frame-

it occurred to me that you might like to glance through a book which applies to the elucidation of mental science, the hypothesis to which you refer. I therefore beg your acceptance of Psychology which I send by this post.

With much sympathy yours, HERBERT SPENCER ${ }^{2}$

Spencer's motives for sending this letter, and a copy of his book, to Tennyson are unclear; perhaps he simply wanted to borrow a little of Tennyson's cultural prestige by associating his work with that of the Poet Laureate. But it is significant that one of the most influential psychologists of the Victorian period should perceive a connection between his theories and a poem that was written two decades before the publication of those theories. His letter indicates that the investigations of the mind in Tennyson's early work continued to resonate with readers throughout the nineteenth century, and that Tennyson's poetry could be read by his contemporaries as making a contribution to the study of the mind.

Having said this, it is important to keep in mind the differences between Spencer's theories and the conception of "mind and frame" that Tennyson puts forward in "The Two Voices". In his desire to appropriate the poem to his cause, Spencer gives a selective reading of Tennyson's lines. The triplet that he quotes forms part of a passage 
in which the speaker of "The Two Voices" attempts to fight off his suicidal misery by arguing that his existence transcends his earthly life, that he is an "old soul in organs new" (I.393). ${ }^{3}$ The predominant focus of this passage is on the progress of the soul rather than on any sort of physical development. The Principles of Psychology, conversely, is a rigorously materialist account of psychology, presenting the mind as the product of physical evolution. Spencer claims that thought and behaviour are "determined by those psychical connections which experience has generated- either in the life of the individual, or in that general antecedent life whose accumulated results are organized in his constitution."4 These different emphases may explain why the "sympathy" that Spencer expresses in his letter to Tennyson does not seem to have been reciprocated. There is no evidence that the poet ever replied to the letter, and his copy of The Principles of Psychology, now at the Tennyson Research Centre in Lincoln, is not exactly well-thumbed: apart from those of the first section, all of its pages remain uncut. It appears that although Tennyson started to read the book, he did not get very far with it.

It is hardly surprising that Tennyson, a writer whose approach to human nature was based on questioning and doubting, should find Spencer's sweeping systemisation of the development of the mind unsatisfactory. Yet there are genuine affinities between "The Two Voices" and the account of the mind presented in The Principles of Psychology. The language of the lines quoted by Spencer pulls against the seemingly metaphysical stance of the passage as a whole: the concluding emphasis on the word 'frame' highlights the physical dimension of the speaker's hypothetical progress, and the empiricist reference to "experience" implies that development, both psychological and physiological, is directed by interaction with the sublunary world. The phrase "lower lives" suggests the continuing influence of the evolutionary theories in which Tennyson was interested as an undergraduate in the late 1820s. Hallam Tennyson comments that, 
while at Cambridge, his father held the opinion that the "'development of the human body might possibly be traced from the radiated, vermicular, molluscous and vertebrate organisms"” (Hallam Tennyson, 1: 44). In "The Two Voices", the speaker's claim that he has not always existed "in human mould" (I.342) implies the existence of a preceding physical "mould" rather than an immaterial soul, and his collocation of "mind and frame" suggests that human psychology is, as much as the human body, an offshoot of "lower lives". Admittedly, the speaker's argument, a last-ditch effort to resist despair, never becomes clear or coherent. He describes it as “'a random arrow from the brain'” (I.345), a phrase that articulates both Tennyson's awareness of the ambiguity inherent in any attempt to understand the mind and his conviction that mental processes are inescapably tied to the physical body.

"The Two Voices" epitomises Tennyson's approach to psychology in his early poetry: while the poem gestures towards belief in an immortal spiritual element of identity, its attention persistently drifts back to an embodied mind that is shaped by physiology and by empirical experience. As a dialogue between the depressed speaker and an insidious internal voice that urges suicide, "The Two Voices" literalises Tennyson's view, implicit throughout much of his early work, of the embodied mind as a divided and mutable compound of mental states whose operations defy conscious control. Personal experience must have played its part in forming this opinion of the mind. The psychological problems that had dogged Tennyson's father, and that had been inherited to a greater or lesser extent by the poet and his ten siblings, would have been playing on Tennyson's mind during the composition of "The Two Voices"; in early 1833, around the time he began writing the poem, his brother Edward was admitted to an asylum for the insane, where he would remain for the rest of his life. ${ }^{5}$

Tennyson's approach to the mind in his poetry of the 1830 s was shaped by wider cultural and intellectual trends as well as by personal circumstances. This was a decade 
in which British writers on the mind, responding in part to the popularity of phrenology, began to place more emphasis on the role of the brain and the body in mental life and on the composite nature of the mind; a trend that would lead to the development of more formalised theories of physiological psychology from the 1850 s onwards. ${ }^{6}$ The similarities between Tennyson's account of the mind and the later theories of physiological psychologists such as Spencer are partly attributable to the fact that, through the books in his father's library, the young Tennyson had access to many fields of enquiry (such as physiology, empiricist philosophy, and associationist psychology) that were subsequently influential in the development of theories of embodied psychology in the second half of the nineteenth century. ${ }^{7}$

During the 1830s, debates within British culture about the body's role in psychology focused largely on the question of insanity. Tennyson would become more closely involved with these debates at the end of the decade through his disastrous friendship with the asylum owner and theorist of madness Matthew Allen. As a younger man, the poet would have read about contemporary developments in the study of the mind and of insanity in particular in the numerous issues of the Quarterly Review that his father collected before his death in 1831. In a review of a book about "nervous affections", published in the Quarterly in 1822, the doctor (and friend of Southey and Coleridge) Robert Gooch analyses mental pathology using language suggestively similar to that of Tennyson's accounts of the fragility of the embodied mind:

In this state, the ideas are moved, one minute by the will, the next by something else; one minute we can command them, another we feel them slip out of our grasp, and whirl across the mind with indescribable fleetness, guided, or rather hurried on, by some impulse strange to and stronger than ourselves. Insanity is a state in which the operations of the mind cease to be governed by intellectual laws, and become subservient to bodily impulses.

For Gooch, while the uncontrollable "impulse" that defies the will appears to exist outside of "ourselves", its origins actually lie in internal physiological processes. He argues that 
the mental state that he describes offers "an experimental demonstration of the double nature of our being, of the physical and moral impulses of our thoughts, which are here brought into contact and comparison." $\mathrm{A}$ similar sense of the mind's "double nature" is played out in the conceptual contest between the body and the soul in "The Two Voices" and in the poem's dialogic form.

Like most writers on insanity in the first half of the nineteenth century, Gooch diagnoses the body's influence on the mind as pathological. However, the frequency with which Tennyson returns to the embodied mind in his early poetry suggests that, although he was not always happy about it, he saw the influence of the body as a more fundamental element of psychology. His handling of the irrepressibly nihilistic voice in "The Two Voices" goes further than Gooch's account of the difficulty of controlling certain thoughts to suggest that mental processes might be inherently chaotic and unruly. Nevertheless, the presence of articles such as Gooch's in an established publication like the Quarterly shows that ideas about the mind's multiplicity, and its relationship to the body, were prominent within the intellectual culture in which Tennyson grew up.

The poet also encountered these ideas through another, particularly influential source: Arthur Hallam. In the papers that he delivered to meetings of the Cambridge Apostles, and in his other writings, Hallam is both fascinated and distressed by the unstable materiality of the mind, and a similar appalled fascination is evident in the poems that Tennyson wrote around the time of Hallam's death in September 1833. In "The Two Voices" and in the dramatic monologues "St Simeon Stylites", "Tithon", and "Ulysses" Tennyson explores the implications of Hallam's approach to psychology. These poems all suggest that the mind, rooted in a fragile physiology and determined by empirical conditions, is both divided and changing, a collection of processes rather than a cohesive entity. This conception of the mind is traceable in many earlier poems, most 
notably the quasi-dramatic monologue "Supposed Confessions of a Second-Rate Sensitive Mind Not in Unity with Itself" published in 1830, but it becomes central to Tennyson's art in the poems that he composed in 1833. While Tennyson started writing "The Two Voices" and "St Simeon Stylites" before Hallam's death, it is easy to picture him thinking over Hallam's theories as he continued working on the poems after the event, and it is equally easy to imagine his grief sharpening his sense of the impermanence of both the body and the mind.

In his essay "On Sympathy", written in 1830, Hallam argues that personal identity is inherently mutable: "It is an ultimate fact of consciousness, that the soul exists as one subject in various successive states." While this statement seems to cast doubt on the notion of a unified self, Hallam is quick to assert that the metaphysical soul provides an underlying "unity of subject" that preserves the ultimate cohesion of identity. ${ }^{9}$ The source of Hallam's interest in the "successive" nature of consciousness is revealed in a letter that he wrote to Tennyson just months before he read "On Sympathy" to a meeting of the Apostles. Here he tells Tennyson what he is reading when not studying with his father: "I take occasional plunges into David Hartley... for my own gratification." ${ }^{10}$ In the associationist model of psychology put forward in his Observations on Man, first published in 1749, Hartley argues that the mind functions by combining into sequences transient ideas that have their origin in "infinitely divisible" physical sensations. These sensations are conveyed to the brain through "vibrations" in the body's nervous tissue, and Hartley concludes from this that ideas, the mind's responses to sensations, must also be neurological in nature:

Since therefore sensations are conveyed to the mind, by the efficiency of corporeal causes upon the medullary substance, as is acknowledged by all physiologists and physicians, it seems to me, that the power of generating ideas, and raising them by association, must also arise from corporeal causes. ${ }^{11}$ 
Hallam took up the physiological focus of Hartley's account as well as its associationism. In his "Essay on the Philosophical Writings of Cicero", written a year after "On Sympathy", he argues that "the analysis of mind" undertaken by "inductive philosophers" (such as Hartley, presumably) has refuted the notion that the essence of mind is "simple and ultimate", and has demonstrated "the dependent, composite, and divisible character of the only thinking and feeling substance". ${ }^{12}$

Although Hallam espouses a belief in the "unity" of the soul in "On Sympathy", the idea that the mind, dependent on a composite and divisible substance, might itself be composite and divisible also features prominently in the essay. Hallam acknowledges the unsettling implications for personal identity that are inherent in his description of the mind's mutability:

To know a thing as past, and to know it as similar to something present, is a source of mingled emotions. There is pleasure, in so far as it is a revelation of self; but there is pain, in so far that it is a divided self, a being at once our own and not our own, a portion cut away from what we feel, nevertheless, to be single and indivisible. (Hallam, "On Sympathy", p.138)

The metaphysical soul is the ostensible subject of this essay, but Hallam's description of the mental process of memory foregrounds the fragmentation of identity that takes place within the empirical mind. The act of remembering highlights the fact that the past self and the present self are distinct; while we may "feel" that the self is "single and indivisible", close attention to the operations of the mind reveals that the mental states that make up our identity are in fact, to use Hartley's phrase, "infinitely divisible".

The psychological division across time that Hallam describes in "On Sympathy" becomes a synchronous division in "The Two Voices"; the composite nature of the embodied mind engenders the poem's psychological duality and denies the speaker control over his mental processes. Early on, he attempts to silence the sceptical voice by invoking the gift that "'Nature'” has bestowed on "'man"” (II.17-18):

"She gave him mind, the lordliest 
Proportion, and, above the rest,

Dominion in the head and breast." (II.19-21)

The confidence with which these lines present "mind" as humanity's crowning glory, accompanied by a sovereign will that guarantees "dominion" over the physical domains of thought and feeling, is only surface-deep. It is undermined by the dialogic structure of the poem, and also, more immediately, by the form of this particular stanza. The monotony of the triple rhyme imparts a strained and unconvincing insistence to the lines, and the assertion of "dominion" is disrupted by the under-stressed metre. The iambic progress of the first line falters on its weak final syllable, and the awkwardness of stressing "and" in the second line and "in" in the third creates a tentative and stuttering metre that is an unpropitious vehicle for the stanza's declamatory language.

Furthermore, the phrase "head and breast", with its explicit division of the self and its allusion to psychology's ties to the body, upsets any conception of the mind as an integrated and autonomous unit. A manuscript version of this stanza locates man's dominion in the "heart and breast"; the use of "head" in the published version both intensifies the stanza's psychological focus and heightens its sense of internal division. ${ }^{13}$ "Proportion", too, is an unsettling word; it seems to suggest that the mind is not an entity in itself but a relation between other entities, perhaps the head and breast. The online OED, however, quotes this line as an example of "proportion" meaning "Form, shape; configuration (of the limbs of the body, etc.); a likeness, a figure." Either sense of the word complicates the stanza's assertions, implying that the mind is in some way a composite or material phenomenon. Tennyson often suggests that there is something lordly about the mind's powers, but these powers are, for him, neither reliable nor controllable, because they originate in a psychology that is inherently contingent and fragmented. 
Throughout "The Two Voices" it is the voice that overtly presses the claims of the embodied mind, insisting that the speaker's identity is shaped by and will end with his physical existence. The voice connects the speaker's psychological disturbance to physical illness by claiming that he lacks "'a healthy frame, a quiet mind"” (I.99). Although the speaker himself collocates the mind with the frame later in the poem, he persistently strives to affirm his faith in the existence of an immortal and immaterial soul. But, as in the "dominion" stanza, his language undermines his arguments by drawing attention to the fragility of the embodied mind. At one point he attempts to refute the idea, central to associationist and empiricist theories, that human psychology is defined by experience, denying that the mind of man is dependent on the "simple senses"' (I.277) and asking the voice:

"Who forged that other influence, That heat of inward evidence, By which he doubts against the sense?" (II.283-5)

Christopher Ricks interprets the language of this stanza as an "invitation to scepticism", arguing that "in a discussion of falsity the word 'forged' is so maladroit as to invite the suspicion of some unconscious adroitness deep in Tennyson." ${ }^{14}$ Perhaps this adroitness was not unconscious; perhaps the ambiguity that pervades the speaker's language represents a deliberate disruption of his argument on Tennyson's part. As well as the use of "forged", there is the revealing fact that the "heat of inward evidence", itself a curiously empiricist description of what is presumably meant to be a priori knowledge, does not produce any assurance but rather another form of doubt. In some of his late poems Tennyson uses this doubt to resist what he sees as reductive materialist accounts of the universe and to reaffirm his belief in the divine, but it is presented here with far less rhetorical confidence. The implication of this stanza seems to be that, while the senses cannot be trusted, choosing to rely instead on any sort of "inward evidence" will only exacerbate psychological confusion. 
The speaker's metaphysical claims falter like this throughout the poem, and nowhere more than in the passage (II.346-84) which he describes as "a random arrow from the brain" and in which his arguments for the existence of a transcendent and unchanging soul end up, persistently and perversely, highlighting the fragmented and mutable nature of the mind. Suggesting that he may have no memory of the past existence of his soul, the speaker compares himself to "men" who "from cells of madness unconfined, / Oft lose whole years of darker mind'” (II.370-2). This comparison of spiritual existence to a forgotten madness is bathetic more than anything else; it does little to support the speaker's argument for the immortality of his soul, but it does draw attention to the weakness of the earthly mind that can succumb both to derangement and to memory loss. A few lines earlier the speaker uses another problematic simile to suggest that his soul's past might be hidden from his consciousness:

"As here we find in trances, men Forget the dreams that happen then, Until they fall in trance again." (II.352-4)

While these references to "madness", "trances", and "dreams" purport to affirm the immortality of the soul, their effect is to relegate the soul to the poem's background, as the metaphysical psychology that the speaker claims to advocate is undermined by his focus on the transience and unreliability of mental processes.

By using the phenomenon of "trance" as evidence for the metaphysical permanence of identity with such ambiguous results, Tennyson is almost certainly responding to Coleridge; as Peter Allen has noted, Coleridge's writings were a crucial intellectual influence on the Cambridge Apostles of Tennyson's generation. ${ }^{15}$ In the Biographia Literaria Coleridge recounts the story of an uneducated German woman who spoke fluent Latin and Greek when she fell into periodic trances, and uses the narrative as supporting evidence for his critique of Hartleyan associationism and its account of the mind as a succession of transient mental states. He traces the origins of the woman's 
condition to her unconscious memories of her childhood, and concludes that the case shows "that all thoughts are in themselves imperishable" and that hence personal identity is equally imperishable. ${ }^{16}$ The speaker of "The Two Voices" is trying to follow the same line of argument, looking to the intermittent but enduring memories of "trance" for proof of the unity of identity that Coleridge, and Hallam in "On Sympathy", locate in the metaphysical soul. But Tennyson's poem, like Hallam's essay, is ultimately closer to the associationist model of psychology that the Coleridge of the Biographia Literaria finds so objectionable. The language of "The Two Voices" evokes the fragmented mind far more forcefully than it does the cohesive soul, just as the poem's dialogic form precludes psychological integrity and makes the fragmentation of the mind its structuring principle and its central concern.

The differing responses of these authors to the same mental phenomenon reflect a wider shift in literary approaches to the mind that took place in the early decades of the nineteenth century. In his study of Victorian poetry's relationship to "mental science", Ekbert Faas argues that, while both Romantic and Victorian poets were interested in delineating mental processes, for the Victorians these processes "ceased to be means to the end of higher metaphysical insights. Stripped of such philosophical pretensions, they are dealt with in more strictly psychological terms."17 This is broadly accurate: Victorian poets unquestionably shy away from the boldly metaphysical assertions of the mind's transcendent potential that were sometimes voiced by their Romantic precursors. However, the distinction is not absolute, certainly not in the case of Tennyson. Often in his poetry, and most famously in section XCV of In Memoriam, the contemplation of mental processes prepares the grounds for moments of metaphysical insight, but these moments are always problematic for Tennyson, ambiguous and circumscribed by the mind's embodied status. Faas also neglects to mention that, as Alan Richardson has convincingly argued, poets such as Keats and the younger Wordsworth and Coleridge 
were profoundly interested in empiricist and somatic approaches to the mind, and that there is "an antidualistic, materialist register within Romantic writing" that pushes against its "idealistic and transcendental conceptions of mind". ${ }^{18}$ The multivalent accounts of the mind put forward by Romantic poets would have been some of the most important influences on Tennyson's approach to psychology.

In this instance, however, the "trance" stanza and the overall structure of "The Two Voices" have less in common with Coleridge's account of the mind in the Biographia Literaria than with later Victorian theories of "double consciousness". Starting with the work of the doctor Henry Holland, double consciousness became, in the 1840s, a vogue term for classifying psychological conditions, such as trances, that appeared to split the mind between separate mental states. Its growing prominence was linked to advances in the study of neurology and anatomy that led to greater knowledge of the hemispheric structure of the brain. Holland defined double consciousness as a condition in which

the mind passes by alternation from one state to another, each having the perception of external impressions and appropriate trains of thought, but not linked together by the ordinary gradations, or by mutual memory. ${ }^{19}$

The closeness of this definition to the lines from "The Two Voices", which were composed before the first publication of Holland's Medical Notes and Reflections in 1839 , is most evident in the emphasis that both place on the separation of the two states of consciousness through the fragmentation of memory.

Holland's conception of double consciousness did not interfere with his belief in the ultimate unity of the mind. For him, the condition was caused by a pathological failure of the two cerebral hemispheres to work together, by the "incongruous action of this double structure, to which perfect unity of action belongs in the healthy state" (Holland, p.172). However, the psychologist Arthur Ladbroke Wigan, writing in 1844, took the argument further, claiming that the two cerebral hemispheres were two separate 
organs, each one the site of a separate mind. In a healthy psychology, according to Wigan, one of these minds predominates over the other, but he identifies in mental pathology a "double process" of thought which "takes the form of a colloquy between the diseased mind and the healthy one", a formulation that irresistibly calls to mind the dialogue of "The Two Voices". ${ }^{20}$ Few writers went as far as Wigan in arguing for the duality of the mind, but the idea that there was a certain level of division inherent in human psychology, and that this division was somehow tied to the structure of the brain, became more widely accepted as the century progressed. "Double consciousness" took on a more wide-ranging role as a term that could denote any sort of mental division or conflict between incompatible trains of thought. By conveying its speaker's misery through an internal dialogue "The Two Voices" presents an account of a divided psychology that closely anticipates later Victorian models of the duality of the mind and the brain.

By turning psychological division into a literal dialogue the poem also pre-empts, by some twenty years, Matthew Arnold's disapproving analysis of modern poetry's preoccupation with "the dialogue of the mind with itself" ${ }^{21}$ The voice mockingly tells the speaker: “Sick art thou- a divided will”' (I.106). This division, and the lack of control over the mind that it engenders, is embodied in the form of the poem and in the structure of this particular line, as one aspect of the mind addresses another using the secondperson pronoun, literally breaking the mind up into separate subjectivities. However, the voice is being disingenuous when it labels the divided speaker "sick". "The Two Voices" ostensibly charts the speaker's progress from pathological duality to stable mental unity, as his reconnection with the social institutions of church and family ultimately allows him to proclaim that "The dull and bitter voice was gone" (I.426). Yet after silencing this voice he immediately begins conversing with another internal voice, albeit a more positive one. The title of the poem describes a binary, but the fragmentation of the mind goes beyond 
this: there are three voices in "The Two Voices", and the poem presents a mind that, even as it changes, remains permanently and essentially divided.

In many ways "The Two Voices" exemplifies what Isobel Armstrong describes as the Victorian "double poem", the poem as the site of "endless struggle and contention". ${ }^{22}$ This poem's duality is written into the formal dialogue between its voices, into the contest between spiritual and embodied accounts of the mind that runs through it, and into an ending that appears to enact psychological integration while simultaneously reaffirming mental division. Moreover, "The Two Voices" shows that Tennyson's characteristic poetic ambivalence is inescapably bound up with his sense of the divisions within individual identity; the psychological dialogue that Arnold deemed morbid and enervating is presented in this poem as a fundamental feature of the mind.

The dialogue of "The Two Voices" is perhaps an excessively literal delineation of the divided mind, but Tennyson refined his representation of psychology in other poems that he wrote in 1833. His approach to psychology arguably finds its best expression in the segmented and self-questioning structure of In Memoriam, which he started writing at this time, but it would take him another 17 years to fashion the poem that would present his most sustained examination of the mind into its final form. In the meantime he used some of the earliest Victorian dramatic monologues to address the same subject in a more condensed format. Herbert F. Tucker has identified Tennyson's handling of the dramatic monologue as a development of the dialogic form of "The Two Voices"; he comments that, after working on this unresolved psychological dialogue, Tennyson proceeds to "give lyric voice to speakers who are dipsychic if not polypsychic, whose monologues form tense, split, shot-silk texts that are anything but monological." ${ }^{23}$ The monologues that Tennyson wrote in 1833 reaffirm his debt to contemporary models of the embodied mind and to Hallam's reading of Hartleyan associationism in particular. "St Simeon Stylites", "Tithon", and "Ulysses" all present themselves as the products of 
composite minds that are being transformed by the empirical conditions that press on them. In each of these monologues the speaker, like the speaker of "The Two Voices", reveals, often against his stated will, that his mind is inescapably bounded by his bodily existence.

The speaker of "St Simeon Stylites" tries to locate his identity in a metaphysical soul and to separate this soul from the body. When he labels his body "this home / Of sin, my flesh, which I despise and hate" (II.56-7), his attribution of sin to the flesh is meant to highlight by comparison the purity of his saintly spirit. His statement also separates the body from the mind by occluding the very existence of sins of the mind, but it is precisely this psychological type of sin (pride, self-obsession, and the rest) of which the reader finds Simeon guilty. Despite Simeon's protestations, the poem connects the mind to the body through his own words, which suggest that his psychological condition has been shaped by his physical circumstances: he calls himself "I, Simeon, whose brain the sunshine bakes" (I.161). The almost grotesque physicality of this statement irresistibly draws attention to the way in which Simeon's body influences his mind. The state of his brain affects his mental state, and the physical deprivations to which he has subjected himself inevitably contribute to the psychological confusion that becomes apparent over the course of the poem.

Like Hallam in "On Sympathy", Simeon feels that the processes of memory have alienated him from his past self, but Tennyson's monologist goes further than Hallam by casting doubt on the trustworthiness of those processes:

I think that I have borne as much as thisOr else I dream- and for so long a time, If I may measure time by yon slow light, And this high dial, which my sorrow crownsSo much- even so.

And yet I know not well, For that the evil ones come here, and say, "Fall down, O Simeon: thou hast suffered long For ages and for ages!" then they prate 
Of penances I cannot have gone through,

Perplexing me with lies; and oft I fall,

Maybe for months, in such blind lethargies

That Heaven, and Earth, and Time are choked. (II.91-102)

Simeon's opening statement here is tentative enough, but it is further undermined by his suggestion in the next line that his memory may in fact be a dream. He has no purchase on his mental processes, which operate beyond his control. His effort to silence his doubts about his memories and to resolve his internal conflict with a full-stopped "even so" collapses immediately as the next verse paragraph opens with another statement of uncertainty. Whether the "evil ones" who speak to Simeon are real people or hallucinations is largely irrelevant; what perplexes him is his own unreliable mind. The only possible solution for Simeon in the face of his chaotic thoughts seems to be to escape consciousness altogether. His fall into "blind lethargies" exposes the mind's physical fragility, as both body and mind shut down under the pressure of the uncontrollable randomness of mental processes.

"St Simeon Stylites" is an exemplary dramatic monologue in the way that the form of the verse and the patterns of Simeon's speech work, sometimes in unison and sometimes in juxtaposition, to convey the processes of his mind. At the start of this passage Simeon's mental division is voiced in the qualification "or else" and is also encoded in the poem's form, as the second line forces the reader to reappraise the meaning of the syntactical unit that forms the first line. Simeon's expressions of selfqualification show that his mind is changing from one moment to the next, but Tennyson's positioning of them across line-breaks and in the gaps between verse paragraphs means that they also come to look like dramatically-scripted elements of a synchronous dialogue, internal reflections of the external dialogue that takes place between Simeon and the "evil ones". Simeon's mind is divided both across time and within each moment, and evidence of this thoroughgoing psychological division surfaces 
throughout his monologue. Early in the poem he states that "my end draws nigh; / I hope my end draws nigh" (II.35-6), and later he similarly declares that he has reached "the end! The end! / Surely the end!" (II.198-9). In both cases the reader is forced to reassess the first line, which seems to finish on an assertion of fact, in light of the opening of the second. In the first example Simeon's peremptory declaration is revealed to be nothing more than an expression of hope, while in the second his use of "surely", which should reinforce the strength of his claim, instead strikes a desperate and pleading note that subverts the declamatory confidence of the preceding line.

It is significant that many of the moments in which Simeon reveals the divided and mutable state of his mind should centre on his desire for an ending. Robert DouglasFairhurst has argued that doubt about the possibility of reaching a definite conclusion is written into the form of Tennyson's blank verse poems, because "blank verse always threatens to sound incomplete until it is linked into a more extended stretch of narrative thought." 24 This sense of incompleteness, traceable throughout the blank verse of "St Simeon Stylites", connects the poem to associationist accounts of the mind as a mutable succession of mental states. The psychological alterations embodied in the form of the poem are the constituent elements of Simeon's mind, and he is powerless to bring them to a halt. Throughout the poem Simeon longs for an end to his physical suffering, and death, the only state in which this suffering will abate, is also the only state which can put an end to his mental turmoil. What happens after this ending, whether and how Simeon's immortal soul will continue to exist independent of his body, is debatable. But the end is not possible while he continues to live and think, because his embodied mind is made up of a disputatious procession of thoughts which precludes psychological rest.

The speaker of "Tithon", the unpublished 1833 draft of "Tithonus", longs like Simeon for an end to his painful existence. Having been granted immortality, he now laments his earlier wish to live "beyond the goal of ordinance / Where all should pause, 
as is most meet for all" (II.22-3), the repetition of "all" indicating the strength of his conviction that the end offered by death is a necessary element of existence. Like "St Simeon Stylites", this poem suggests that death is the only state in which the mind can "pause", and that, in life, thought and feeling are inherently painful:

Ay me! ay me! what everlasting pain, Being immortal with a mortal heart, To live confronted with eternal youth: To look on what is beautiful nor know Enjoyment save through memory. (II.11-15)

In the original myth, Tithonus's problem is specifically physical: his immortality is marred by his aging and decaying mortal body. Tennyson, by placing the speaker's "everlasting pain" in his "mortal heart", subtly shifts the focus of the story. Kirstie Blair has shown that Victorian writers were acutely aware of the dual nature of the heart, its "status as a physical organ with spiritual connotations". ${ }^{25}$ Tennyson's use of "heart" here makes Tithon's predicament both physical and, if not spiritual, then psychological: it roots his suffering in his body while simultaneously hinting that his consciousness, his emotions, and his personality, inextricably bound up with his physical organs, are also fragile and mortal. This speaker's unique corporeal circumstances, his existence in and as a body that is growing eternally weaker, make him far more prepared than Simeon to acknowledge the embodied nature of his mind.

Although Tithon's pain is connected to his heart, Tennyson more usually locates his speakers' anguish in their brains. ${ }^{26}$ The use of "heart" in "Tithon" was no doubt partly motivated by a desire to avoid the inclusion of a rhyme in the poem's blank verse, but it is also apposite in the sense that, in these lines, the workings of the mind (and by extension of the brain too) offer some relief from pain in the form of the "enjoyment" that Tithon derives from his memories of his youth. Yet memory's powers of consolation are limited; Tithon shares Arthur Hallam's belief that the act of remembering is a source of both comfort and disquiet: 
Ay me! ay me! with what another heart,

By thy divine embraces circumfused,

Thy black curls burning into sunny rings,

With thy change changed, I felt this wondrous glow

That, gradually blooming, flushes all

Thy pale fair limbs: what time my mortal frame

Molten in thine immortal, I lay wooed. (II.41-7)

Like Hallam, Tithon presents his memories as having happened to a different person: his mortal self possessed "another heart". Tithon is, of course, an extreme case, as his immortality heightens his awareness of the gap between his past and his present to an extraordinary pitch. Nonetheless, these lines suggest that the unsettling mutability of identity is an inevitable consequence of lived experience. Tithon's comment to his lover Aurora, goddess of the dawn, that he "with thy change changed" suggests that emotional and psychological changes are as frequent and as irresistible as the dawn itself. This passage's account of the sensual responsiveness of the body doubles as an invocation of the dawn, but the bodily changes that it delineates also reflect, and to some extent cause, the changes taking place within Tithon's consciousness. The description of the "mortal frame / Molten" into another body, with its alliteration flowing over from one line into the next, captures both the physical basis of emotional experiences such as lust and grief and the power of those experiences to transform the mind.

In "Tithonus", the revised version of "Tithon" that Tennyson published in 1860, the speaker's examination of memory goes further, suggesting that the mutability of the mind might lead to its total fragmentation:

Ay me! ay me! with what another heart In days far-off, and with what other eyes I used to watch- if I be he that watchedThe lucid outline forming round thee. (II.50-53)

This version of the passage heightens the sense of physical alteration: Tithonus's past self had "other eyes" as well as "another heart". Even more important for the passage's psychological stance is the insertion of the qualifier "if I be he". As Ricks points out, in 
this phrase "a skill in miniature- a pronoun- effects something not miniature at all" (Ricks, Tennyson, p.123). Like the pronouns of "The Two Voices", the pronouns of line 52 describe mental division, although here it is division across time, suggesting that Hallam's ideas about the divided and successive nature of the mind were prominent in Tennyson's own mind when he revisited his past to revise "Tithon" after a gap of almost 30 years. The bare simplicity of the phrase "if I be he" intensifies the impact of its claim that the physical and mental changes an individual undergoes over time might so alter identity that past and present selves become separate subjects requiring separate pronouns. Writing more than a decade before the publication of Walter Pater's The Renaissance, Tennyson anticipates Pater's argument, in the conclusion to his book, that the ephemeral nature of individual identity has its roots in the "perpetual motion" of physical processes: "the passage of the blood, the waste and repairing of the lenses of the eye, the modification of the tissues of the brain under every ray of light and sound". ${ }^{27}$ Characteristically, Tennyson's speaker is less sanguine than Pater about possessing "other eyes". Tithonus longs for death because it will bring to an end the preternaturally lengthy sequence of physical and psychological changes that have so fragmented his self-conception.

In the revised conclusion of the poem, Tennyson employs another "skill in miniature", this time in his use of prepositions, to suggest that death enables a restful resolution that is not feasible in life. Tithonus predicts to Aurora that, should he die, "thou wilt renew thy beauty morn by morn; / I earth in earth forget these empty courts" (II.74-5). Cornelia Pearsall has argued that Tithonus sees his physical decay as a "dialectical process" not dissimilar to his lovemaking with Aurora, as both "involve for him the slow and staggered diffusion of the self into another entity, a submission of personal agency and bodily control". ${ }^{28}$ However, there is a difference: unlike his relationship with Aurora, Tithonus's absorption into the earth is not a process of ongoing change. It has a definite 
terminal point, a fact demonstrated by the prepositions used in these lines. The "by" of "morn by morn" confirms that Aurora will continue her daily transformations ad infinitum, while the "in" of "earth in earth" conveys a sense of a fixed consummation in death that Tithonus cannot find in the dynamic mental and physical processes that constitute life. His willingness to accept the embodied nature of his mind allows him to imagine a more certain end than Simeon's and to hope that a physical death, without the possibility of an afterlife, will grant him relief from the hardship of unstoppable thought and feeling.

"Ulysses", written around the same time as "Tithon" and "St Simeon Stylites", differs from those poems in being voiced by a speaker who vehemently refutes the desirability of coming to an end: "How dull it is to pause, to make an end, / To rust unburnished, not to shine in use!" (II.22-3). Like Tithon, Ulysses imbues the word "pause" with a sense of finality, as if even a moment of stillness might result in a permanent and irreversible ending. Ulysses's conviction that if he is not moving then he is as good as dead is evident from the opening lines of the poem: "It little profits that an idle king, / By this still hearth, among these barren crags" (II.1-2). The prepositions "by" and "among" insistently trap Ulysses in a specific location, and the list of adjectives that he resentfully recites- "idle", "still", "barren"- shows that his dissatisfaction with life stems precisely from his inactivity.

Despite this difference in attitude, Ulysses shares with Tithon and Simeon the belief that change constitutes life and that fixity and resolution are equivalent to death. His restlessness is typically read as physical or political frustration, but it can also be seen in psychological terms. As the speaker of a dramatic monologue, Ulysses is literally speaking his mind; for all his talk of moving on, the action of the poem and the changes that are described within it and that take place over its course are psychological rather than physical. The poem presents an empiricist account of psychology in which Ulysses, like Tithon and Simeon, implicitly recognises that the experiences which he has 
undergone have shaped and altered his identity. Unlike the other two monologists, however, Ulysses, in his concluding address to the mariners, articulates his appetite for new experiences and new changes that will prolong his existence:

Though much is taken, much abides; and though

We are not now that strength which in old days

Moved earth and heaven; that which we are, we are;

One equal temper of heroic hearts,

Made weak by time and fate, but strong in will

To strive, to seek, to find, and not to yield. (II.65-70)

Although Ulysses insists that "much abides", the emphasis of these lines is on the transient over the abiding. Ulysses's mind and body have been transformed over time; the dual nature of the change is again signified by Tennyson's reference to the heart. These transformations have left Ulysses physically "weak" and irrevocably changed: like Tithon, although obviously to a lesser extent, he is not the man he used to be. His assertion "that which we are, we are" is an attempt to construct a fixed (collective) identity for himself and his mariners, but its flat tautological repetition offers scant consolation for what has been "taken", for the absence of what "we are not now".

The impossibility of bridging the gap between present and past selves casts doubt on Ulysses's seemingly triumphant celebration of will in the final lines by suggesting that however "strong in will" he may be, he is powerless in the face of "time and fate". The strength of Ulysses's will is itself called into question through the awkwardly irresolute tone introduced into this passage by "though" and "but"; his frequent qualification of his own statements creates the impression of a divided mind that cannot will itself into decisiveness. Even the assertion of will in the final line, which seems so unambiguous, is rhythmically and syntactically disrupted by the insertion of the negative near its end and is further undermined by the conclusive emphasis placed on the word "yield". The critic Goldwin Smith, writing about "Ulysses" in 1855, suggested that the poem's speaker 'intends to roam, but stands for ever a listless and melancholy 
figure on the shore. ${ }^{29}$ His ultimate fate is a matter of conjecture, but the poem's final lines offer no assurance that he has the capacity to convert the dictates of the will into action. The dominion over the mind that the speaker of "The Two Voices" invokes but struggles to enact is again checked in this monologue as the mind, tied to a frail body and pressed on by empirical conditions, undergoes changes that Ulysses is powerless to control.

The inescapable influence of experience and circumstance on the development and operation of the mind is affirmed by Ulysses's famous self-definition:

I am a part of all that I have met;

Yet all experience is an arch wherethrough

Gleams that untravelled world, whose margin fades

For ever and for ever when I move. (II.18-21)

The last three lines encapsulate the frustrated idealism and reluctant empiricism that characterise much of Tennyson's early poetry. The experiences that make up life appear to lead to the threshold of another world, numinous and metaphysical, that transcends the contingency of empirical existence. Yet this portal to transcendence is forever just out of reach; as Ulysses moves, as his mind changes as a result of his changing experiences, so the "untravelled world" shifts and recedes away from him. However far he travels, he cannot escape the physical world of experience that shapes his psychology.

The ambiguity of the statement "I am a part of all that I have met" leaves the precise nature of the relationship between Ulysses's mind and the empirical world open to debate. This line can be read as an assertion on Ulysses's part that he has left his mark on all that he has met; as a résumé of what Alan Sinfield calls "an imperialism of the imagination". ${ }^{30}$ However, this reading of the line, as a confident proclamation of the power of personal agency, does not sit well with the ambivalence about the will and the emphasis on the intractability of empirical conditions that are traceable throughout the 
monologue. While the wording of the statement allows that Ulysses has exerted an influence on all that he has met, it also reciprocally suggests that his psychology is inseparable from the experiences and circumstances that have influenced it. This empiricist stance implies that, without experience, the mind would be empty and personal identity an abstraction. Such an empiricist reading can be pursued further: if Ulysses's "all that I have met" is taken to mean the whole mass of empirical conditions that have touched him throughout his life, then his psychology becomes just one facet or even offshoot of the circumstances that have produced, among other things, his mind.

This last reading was the one favoured by George Henry Lewes. In the final volume of his psychological treatise Problems of Life and Mind, published in 1879, Lewes quotes Ulysses's "I am a part of all that I have met" to support his view that psychology is determined by environmental conditions. After quoting the line, Lewes proceeds to comment that "we may say with equal truth, though not with equal rhythm, 'I am the product of all that I have felt'”, incorporating Tennyson's poetry into his empiricist argument that the mind is constantly "altered" and "modified" by experience, particularly physiological experience. ${ }^{31}$ The fact that Lewes, a physiological psychologist working in the associationist tradition, turned to "Ulysses" to find support for his theories shows that Tennyson's contemporaries could identify physiological and empiricist postures in his descriptions of the mind if they were looking for them. But the readings of Tennyson made by Lewes and Spencer were not simply tendentious; physiological concepts are genuinely present in the account of the mind put forward in the poet's early writing, despite his intense ambivalence about the implications of such concepts. While Tennyson may have hoped to believe in the existence of a sovereign will and an immaterial soul, his representations of embodied psychology in the poems of 1833 suggest that he was equally drawn to another possibility: that personal identity is the product of an unruly, contingent, material mind. 
${ }^{1}$ I would like to thank Sally Shuttleworth, Helen Small, and Herbert F. Tucker, all of whom gave
invaluable advice during the writing of this piece.
${ }^{2}$ Quoted in Hallam Tennyson, Alfred Lord Tennyson: A Memoir, 2 vols. (London: Macmillan,
1897), 1: 411. The lines quoted by Spencer are II.364-6 of "The Two Voices".
${ }^{3}$ This and all subsequent line references to Tennyson's poetry are from Alfred Tennyson, The
Poems of Tennyson, ed. Christopher Ricks, 3 vols., 2nd ed. (Harlow: Longman, 1987).
${ }^{4}$ Herbert Spencer, The Principles of Psychology (London: Longman, Brown, Green, and
Longmans, 1855), p.617.
${ }^{5}$ Robert Bernard Martin, Tennyson: The Unquiet Heart (Oxford: Clarendon Press, 1980), p.191.
${ }^{6}$ For a summary of the development of theories of mind over the course of the nineteenth century, see Roger Smith, The Fontana History of the Human Sciences (London: Fontana Press, 1997), pp.250-59, 407-20.

${ }^{7}$ Of the theories that Tennyson would have come across in his father's library and that would have helped to shape his thinking about the embodied mind, probably the most important were the classical materialism of Lucretius, the empiricist and associationist philosophies of Locke and Hume, and the various accounts of physiology to be found in his father's books on medicine. Many of George Clayton Tennyson's books are now at the Tennyson Research Centre. See George Moore, "A Critical and Bibliographical Study of the Somersby Library of Doctor George Clayton Tennyson" (master's dissertation, University of Nottingham, 1966); and Nancie Campbell, Tennyson in Lincoln: A Catalogue of the Collections in the Research Centre, 2 vols. (Lincoln: Tennyson Society, 1971-3), 1:1-23.

${ }^{8}$ Robert Gooch, "Reid- On Nervous Affections", in Quarterly Review 27 (1822): 113.

9 Arthur Henry Hallam, "On Sympathy", in The Writings of Arthur Hallam, ed. T.H. Vail Motter

(New York: Modern Language Association of America, 1943), p.137.

${ }^{10}$ Hallam to Tennyson, 04 October 1830, in The Letters of Arthur Henry Hallam, ed. Jack Kolb (Columbus: Ohio State University Press, 1981), p.379.

${ }^{11}$ David Hartley, Observations on Man, his Frame, his Duty, and his Expectations (1791), 2 vols. (Poole: Woodstock Books, 1998), 1: 70, 72.

${ }_{12}$ Hallam, "Essay on the Philosophical Writings of Cicero", in Writings, pp.174-5.

${ }^{13}$ See The Poems of Tennyson, ed. Ricks, 1: 572.

${ }_{14}^{14}$ Ricks, Tennyson, 2nd ed. (London: Palgrave, 1989), p.99.

${ }^{15}$ Peter Allen, The Cambridge Apostles: The Early Years (Cambridge: Cambridge University Press, 1978), p.139.

${ }^{16}$ Samuel Taylor Coleridge, Biographia Literaria (1817), ed. James Engell and W. Jackson Bate, 2 vols., vol. 7 of The Collected Works of Samuel Taylor Coleridge (London: Routledge and Kegan Paul, 1983), 1: 114.

${ }^{17}$ Ekbert Faas, Retreat into the Mind: Victorian Poetry and the Rise of Psychiatry (Princeton: Princeton University Press, 1988), p.175.

${ }^{18}$ Alan Richardson, British Romanticism and the Science of the Mind (Cambridge: Cambridge University Press, 2001), p.36 and passim.

${ }^{19}$ Henry Holland, Medical Notes and Reflections, 2nd ed. (London: Longman, Orme, Brown, Green, and Longmans, 1840), p.174.

${ }^{20}$ Arthur Ladbroke Wigan, A New View of Insanity: The Duality of the Mind Proved by the Structure, Functions, and Diseases of the Brain (London: Longman, Brown, Green, and Longmans, 1844), p.27. For a selection of Victorian discussions of double consciousness and the double brain, including extracts from Holland and Wigan, see Embodied Selves: An Anthology of Psychological Texts 1830-1890, ed. Sally Shuttleworth and Jenny Bourne Taylor (Oxford: Clarendon Press, 1998), pp.123-40.

${ }^{21}$ Matthew Arnold, preface to Poems (1853), in The Complete Prose Works of Matthew Arnold, ed. R.H. Super, 11 vols. (Ann Arbor: University of Michigan Press, 1960-77), $1: 1$.

22 Isobel Armstrong, Victorian Poetry: Poetry, Poetics and Politics (London: Routledge, 1993), p.10 and passim. Seamus Perry discusses the particular relevance to Tennyson's poetry of both Arnold's and Armstrong's formulations in Alfred Tennyson (Tavistock: Northcote House, 2005), p.6. 
${ }^{23}$ Herbert F. Tucker, "Vocation and Equivocation: The Dialogue of Genres in Tennyson's 'The Two Voices'”, in Victorian Connections, ed. Jerome J. McGann (Charlottesville: University Press of Virginia, 1989), p.139.

${ }^{24}$ Robert Douglas-Fairhurst, Victorian Afterlives: The Shaping of Influence in Nineteenth-Century Literature (Oxford: Oxford University Press, 2002), p.215.

${ }^{25}$ Kirstie Blair, Victorian Poetry and the Culture of the Heart (Oxford: Oxford University Press, 2006), p.15.

${ }^{26}$ A search on Literature Online reveals that "pain" is the most common rhyme for "brain" in Tennyson's poetry: http://lion.chadwyck.co.uk/searchTexts.do.

${ }^{27}$ Walter Pater, The Renaissance: Studies in Art and Poetry (1873), ed. Adam Phillips (Oxford: Oxford University Press, 1986), p.150.

${ }^{28}$ Cornelia Pearsall, Tennyson's Rapture: Transformation in the Victorian Dramatic Monologue (Oxford: Oxford University Press, 2008), p.259.

${ }^{29}$ Goldwin Smith, "The War Passages in 'Maud", Saturday Review 1 (1855), in Tennyson: The Critical Heritage, ed. John D. Jump (London: Routledge and Kegan Paul, 1967), p.188.

${ }_{31}^{30}$ Alan Sinfield, Alfred Tennyson (Oxford: Basil Blackwell, 1986), p.53.

${ }^{31}$ George Henry Lewes, Problems of Life and Mind, 5 vols. (London, Trübner and Co., 1874-9), vol. 5, Mind as a Function of the Organism, p.87. 